\title{
Normal values for peripheral blood white cell counts in women of four different ethnic origins
}

\author{
BARBARA BAIN, MARY SEED, IAN GODSLAND \\ From the Departments of Haematology and Human Metabolism, St Mary's Hospital Medical School, London \\ W2 $1 P G$
}

SUMMARY Total and differential white cell counts were studied in 399 women living in the same community in Britain but drawn from four different ethnic groups. The groups were white (northern European), Indian, black (African and West Indian), and Oriental. The total white cell count and absolute neutrophil count were significantly lower in the black group than in each of the other groups. The absolute monocyte count was higher in whites than in each of the other groups. Contrary to earlier reports, the absolute eosinophil count in blacks was no higher than in whites, suggesting that the high eosinophil counts previously found had an environmental rather than a genetic cause. The eosinophil count of Indians was only marginally higher than that of whites and the difference was not significant, again suggesting that high eosinophil counts previously reported had an environmental cause. No ethnic variation was found in the absolute lymphocyte count. The lower white cell count and neutrophil count found in blacks is of considerable practical importance, and blacks should not be assessed in relation to reference ranges derived for whites. Nevertheless, the eosinophil count in healthy blacks is no higher than that of whites and counts above reference ranges for whites should be considered clinically important. The differences between white cell counts of Indians and Orientals and those of whites are minor and for practical purposes they can be assessed in relation to reference ranges derived for whites.

Textbook normal ranges for peripheral blood total differential white cell counts usually relate to Caucasians. In 1941, however, Forbes et al' found that among Mississippi sharecroppers blacks had lower white cell counts and neutrophil counts than whites. This observation was confirmed for American blacks ${ }^{2}$ and was later extended to blacks in east and west Africa ${ }^{3}$ and to Africans and West Indians resident in Britain. ${ }^{4}$ Leucopenia or neutropenia has also been reported in South African Bantus ${ }^{5}$ and in Yemenite Jews, ${ }^{6}$ whereas white cell counts and neutrophil counts are not significantly different from white values in the South African coloured population $^{5}$ or in South African Indians. ${ }^{7}$ Some studies of the white cell counts in subjects of different ethnic origins have used hospital patients rather than healthy subjects. ${ }^{24}$ Others have compared data from the ethnic group being considered with textbook ranges rather than with data from control subjects whose blood counts have been performed and analysed in the same manner. ${ }^{8}$ The need for statistical methods

Accepted for publication 8 November 1983 to deal with a non-normal distribution of white cell counts has not always been appreciated.

We have studied normal values for the total white cell counts and for each individual cell type in healthy subjects of four different ethnic origins all resident in the UK. The groups studied were: white, black, Indian, and Oriental. Several previous studies have been restricted to men. ${ }^{15}$ Our subjects were all women, as the study was part of an investigation into the effect of oral contraceptives on women of different ethnic origins.

\section{Patients and methods}

Most women in this study were volunteers who responded to a printed circular; a few were referred from local family planning clinics. The subjects studied were part of a larger group in whom various effects of oral contraceptives were studied. ${ }^{9}$ The age range of subjects was 16 to 45 years. Women were grouped as white $(100)$, black (158), Indian (90), or Oriental (51). To be included in a group each subject had to have at least three grandparents belonging to that ethnic group. Half of the black group was 
from the West Indies, $30 \%$ from Africa, and $20 \%$ born in the UK of West Indian parents. The Indian group comprised $35 \%$ from India and Sri Lanka, $7 \%$ from Pakistan and Bangladesh, $42 \%$ from east Africa, and $11 \%$ from the West Indies. Subjects in the Oriental group were from south east Asia and were predominantly ethnic Chinese.

Volunteers were assessed as healthy on the basis of a medical history and routine medical examinations; a dietary history was taken. Forty percent of subjects were taking oral contraceptives; preparations being taken contained on average $30 \mu \mathrm{g}$ of oestrogen (ethinyl oestradiol). The percentages of current smokers in each ethnic group were white $30 \%$, black $25 \%$, Indian $9 \%$, and Oriental $16 \%$. All subjects from the larger study whose peripheral blood film was available in the file and on whom a differential count could therefore be done were included in this subsidiary study; as subjects were studied more than once the blood count available for this study was not necessarily the same as that used in the larger study.

Subjects were fasted overnight $(12 \mathrm{~h})$ and were semirecumbent for $30 \mathrm{~min}$ before the blood sample was taken. Venous blood was taken through an indwelling cannula without stasis between 9.00 and $9.30 \mathrm{am} .4 \mathrm{ml}$ of blood was anticoagulated with $\mathrm{K}_{2}$ EDTA and total white cell count was measured on a Coulter Counter, Model S. A five hundred cell differential count was done on a May-GrünwaldGiemsa stained film, cells being counted in longitudinal bands. Absolute counts for each cell type were calculated.

\section{STATISTICAL ANALYSIS}

The total white cell counts and absolute counts for each cell type (with the exception of basophils) had a log-normal distribution. Logarithmic conversion was therefore used for calculating means and $95 \%$ confidence limits. Means of groups were compared by Student's $t$ test.

Counts in women taking and not taking oral contraceptives were compared, and if no significant differences were found the two groups were pooled before comparison with other ethnic groups. A few women were studied both taking and not taking oral contraceptives; when the two groups were pooled only one value (the off oral contraceptive value) was included from these subjects. For the basophils the observed median and $95 \%$ confidence limits were recorded, and grouped counts were submitted to a $\chi^{2}$ test to see if there was any difference between each pair of ethnic groups or between those taking and not taking oral contraceptives.

\section{Results}

TOTAL WHITE CELL COUNT

In the black group subjects taking oral contraceptives had significantly higher white cell counts $(p<$ 0.001) than those not taking oral contraceptives (Table). In the other groups there were no consistent trends or any significant differences. Because of the significant difference between oral contraceptive users and non-users in the black group the two groups were not pooled for comparison of racial groups but non-users of each racial group were

Total white cell count and absolute neutrophil, lymphocyte, monocyte, and eosinophil counts $\left(\times 10^{-9 / l}\right)$ in women of four ethnic origins

\begin{tabular}{|c|c|c|c|c|c|}
\hline & & $\begin{array}{l}\text { White } \\
(n=100)\end{array}$ & $\begin{array}{l}\text { Indian } \\
(n=90)\end{array}$ & $\begin{array}{l}\text { Oriental } \\
(n=51)\end{array}$ & $\begin{array}{l}\text { Black } \\
(n=158)\end{array}$ \\
\hline White cell count & $\begin{array}{l}\text { OFF } \\
\text { ON } \\
\text { ALL }\end{array}$ & $\begin{array}{lll}6.1 & (3.6 & -10.4) \\
6.4 & (3.9 & -10 \cdot 4) \\
6.2 & (3.7 & -10.5)\end{array}$ & $\begin{array}{ll}6.1 & (3.6-10.5) \\
5.8 & (3.8-9.0) \\
6.1 & (3.6-10.2)\end{array}$ & $\begin{array}{lll}5 \cdot 9 & (3 \cdot 9 & -8 \cdot 8) \\
6 \cdot 3 & (4 \cdot 6 & -8 \cdot 6) \\
6 \cdot 0 & (4 \cdot 0 & -8 \cdot 9)\end{array}$ & $\begin{array}{l}4.9(3 \cdot 1-7 \cdot 8) \\
5.65 \quad(3 \cdot 35-9 \cdot 5) \\
5 \cdot 2 \quad(3 \cdot 1-8 \cdot 7)\end{array}$ \\
\hline Neutrophil count & $\begin{array}{l}\text { OFF } \\
\text { ON } \\
\text { ALL }\end{array}$ & $\begin{array}{ll}3.5 & (1.6-7.7) \\
3.7 & (1.9-7.4) \\
3.6 & (1.7-7.5)\end{array}$ & $\begin{array}{ll}3.4 & (1.5-7.4) \\
3.4 & (2.0-6.0) \\
3.4 & (1.6-7.2)\end{array}$ & $\begin{array}{lll}3 \cdot 2 & (1 \cdot 6 & -6 \cdot 3) \\
3 \cdot 3 & (2 \cdot 1 & -5 \cdot 05) \\
3 \cdot 2 & (1 \cdot 7 & -6 \cdot 1)\end{array}$ & $\begin{array}{lll}2.4 & (1.1 & -5 \cdot 2) \\
2.9 & (1.2 & -7 \cdot 0) \\
2.6 & (1.1 & -6 \cdot 1)\end{array}$ \\
\hline Lymphocyte count & $\begin{array}{l}\text { OFF } \\
\text { ON } \\
\text { ALL }\end{array}$ & $\begin{array}{ll}1.8 & (0.9-3.5) \\
1.9 & (1.05-3.4) \\
1.8 & (0.95-3.5)\end{array}$ & $\begin{array}{ll}2.0 & (0.9-4.2) \\
1.7 & (0.9-3.2) \\
1.9 & (0.9-3.8)\end{array}$ & $\begin{array}{l}1.9 \quad(1.1-3.15) \\
2.2 \quad(1.3-3.9) \\
1.95(1.1-3.4)\end{array}$ & $\begin{array}{ll}1.8 & (0.9-3.75) \\
2.0 & (1.2-3.3) \\
1.9 & (1.0-3.6)\end{array}$ \\
\hline Monocyte count & $\begin{array}{l}\text { OFF } \\
\text { ON } \\
\text { ALL }\end{array}$ & $\begin{array}{l}0.44(0.20-1.00) \\
0.38(0.15-0.94) \\
0.41(0.17-0.99)\end{array}$ & $\begin{array}{l}0.34(0.17-0.70) \\
0.32 \\
0.34\end{array}\left(\begin{array}{l}0.12-0.84) \\
0.15-0.78)\end{array}\right.$ & $\begin{array}{l}0.35(0.17-0.69) \\
0.32(0.12-0.89) \\
0.34(0.16-0.74)\end{array}$ & $\begin{array}{l}0.33 \\
0.34 \\
0.33\end{array}\left(\begin{array}{l}0.15-0.76) \\
0.14-0.81) \\
0.14-0.77)\end{array}\right.$ \\
\hline Eosinophil count & $\begin{array}{l}\text { OFF } \\
\text { ON } \\
\text { ALL }\end{array}$ & $\begin{array}{l}0.12(0.02-0.53) \\
0.12(0.02-0.83) \\
0.12(0.02-0.66)\end{array}$ & $\begin{array}{l}0.15(0.02-0.96) \\
0.14(0.04-0.57) \\
0.15(0.04-0.83)\end{array}$ & $\begin{array}{l}0.14(0.02-1 \cdot 12) \\
0.19(0.01-2.94) \\
0.15(0.02-1.35)\end{array}$ & $\begin{array}{l}0.10(0.01-0.84) \\
0.10(0.01-0.85) \\
0.10(0.01-0.82)\end{array}$ \\
\hline Basophil count & ALL & $0.04(0-0.1)$ & $0.03(0-0.12)$ & $0.03(0$ & $0.03\left(\begin{array}{ll}0 & -0.08\end{array}\right)$ \\
\hline
\end{tabular}

Values given as mean count ( $95 \%$ confidence limits).

$\mathrm{ON}=$ subjects taking oral contraceptives; $\mathrm{OFF}=$ subjects not taking oral contraceptives; $\mathrm{ALL}=$ all subjects. 


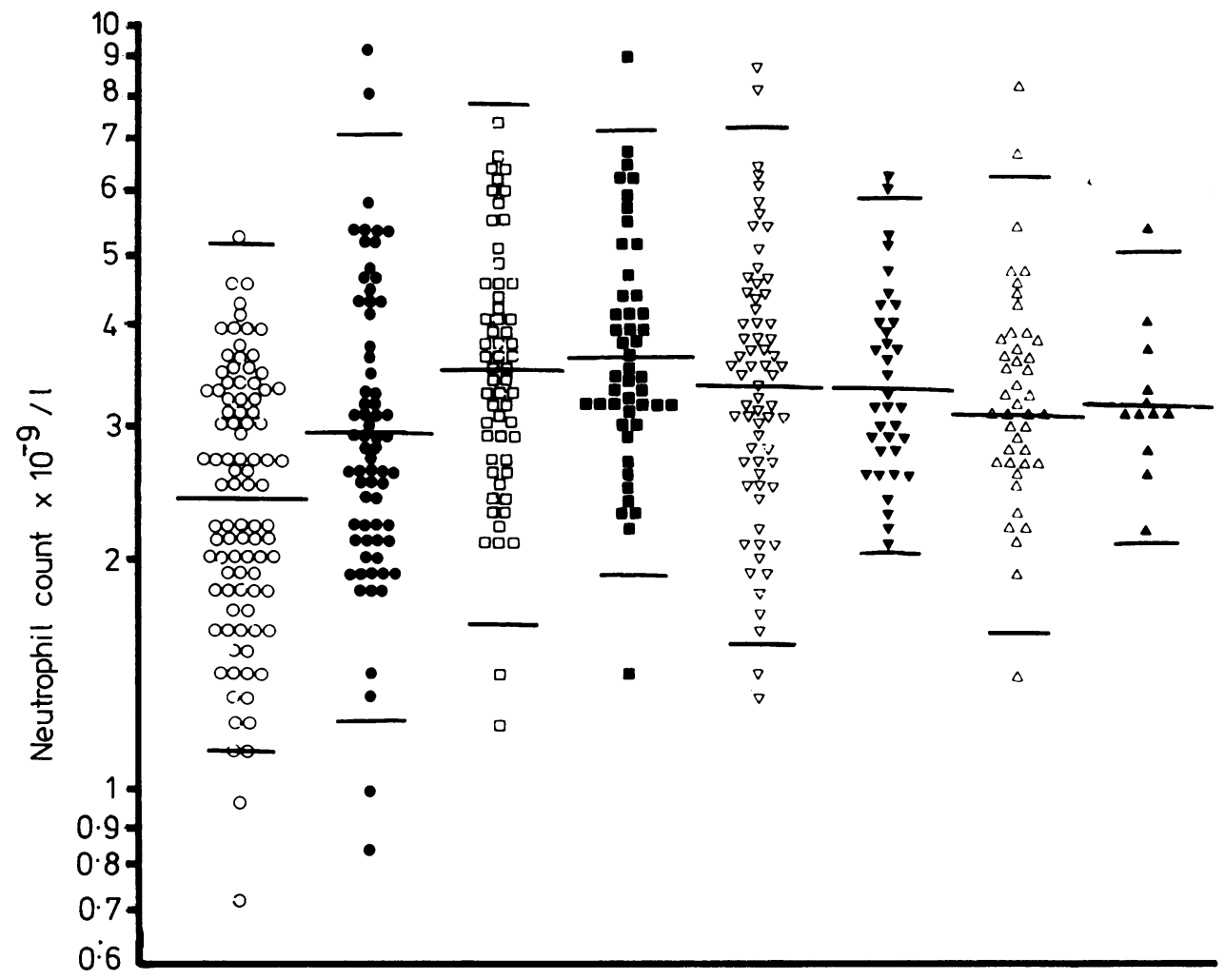

Neutrophil counts $\left(\times 10^{-9} / l\right)$ in women in the four ethnic groups classified into those taking or not taking oral contraceptives $(O C) O=$ black, no $O C ; \quad=$ black, OC; $\square=$ white, no $O C ; \square=$ white, OC; $\nabla=$ Indian, no $O C ; \nabla=$ Indian, $O C ; \triangle=$ Oriental, no $O C ; \Delta=$ Oriental, $O C$. Long horizontal lines indicate mean values; short horizontal lines indicate $95 \%$ confidence limits.

compared. Blacks had significantly lower white cell counts than whites $(p<0.001)$, Orientals $(p<$ $0.001)$, and Indians ( $<<0.001)$, but the three nonblack groups did not differ from one another. Had the oral contraceptive users and non-users been pooled the differences between the blacks and each of the other groups would have remained significant (though with a lower level of significance: $p<0.001$ for whites, $p<0.05$ for Orientals, and $p<0.01$ for Indians). The differences in white cell count between different ethnic groups were not attributable to differences between smokers and non-smokers, which were slight in comparison with the differences between ethnic groups.

\section{NEUTROPHIL COUNT}

The findings in relation to the neutrophil count were similar to those for the total white cell count. There was a significantly higher count in blacks who used oral contraceptives $(p<0.01)$ that in non-users, but no difference was found between users and nonusers in any other racial groups. Blacks also had lower neutrophil counts than whites $(p<0.001)$, Orientals $(p<0.001)$, and Indians $(p<0.001)$, but there were no significant differences between the non-black groups. For both the white cell count and the neutrophil count the magnitude of the difference between blacks and other ethnic groups was greater than the magnitude of the difference between black contraceptive users and non-users (Figure). The difference between the different ethnic groups was not attributable to differences between smokers and non-smokers.

\section{LYMPHOCYTE COUNT}

In contrast to findings for the total white cell count and the absolute neutrophil count the absolute lymphocyte count showed no difference between users and non-users of oral contraceptives, and ranges were similar in groups of different ethnic origins. 


\section{MONOCYTE COUNT}

There were no differences in the monocyte counts between users and non-users of oral contraceptives. The mean monocyte count of whites was significantly higher than that of blacks $(\mathrm{p}<0.01)$, Orientals $(p<0.01)$, and Indians $(p<0.001)$. The three non-white groups did not differ significantly from one another.

\section{EOSINOPHIL COUNT}

There were no differences in eosinophil count between users and non-users of oral contraceptives. There was no difference between the mean eosinophil count of whites and blacks. The mean eosinophil count was highest in Indians, and the difference between Indians and blacks (whose mean counts were the lowest) was significant $(p<0.05)$.

\section{BASOPHIL COUNT}

The distribution of basophil counts was no different between users and non-users of oral contraceptives and showed no significant differences between the four ethnic groups.

\section{Discussion}

We have confirmed that the total white cell counts and neutrophil counts of blacks are significantly lower than those of whites. In addition, their counts are significantly lower than those of Indian and Oriental subjects. Although the mean count in Indian and Oriental groups was lower than in whites, this difference was not significant. The differences between ethnic groups could not be attributed to differences between the white cell and neutrophil counts of smokers and non-smokers.

The cause of the lower neutrophil and white cell counts in blacks is unknown, and it is uncertain whether it is genetic or environmental. Attempts to show a familial basis have been unsuccessful. ${ }^{10}$ An environmental cause was suggested by Ezeilo ${ }^{11}$ on the basis of a comparison of groups of Zambians on African, mixed, or western diets. Shija et al ${ }^{12}$ found that over five years the mean white cell and neutrophil counts of healthy subjects rose considerably, and their figures in 1976 were considerably higher than those of Ezeilo in 1972; ${ }^{\prime \prime}$ they thus supported an environmental cause for neutropenia, though they did not comment on the diet of their subjects. In 1941 Forbes et $a l^{1}$ found an appreciable difference in white cell counts and neutrophil counts between black Americans and white Americans, whereas studies in $1966,,^{2} 1970,{ }^{13}$ and $1972^{14}$ found a smaller difference. One of the subjects of Forbes $\mathrm{et}$ al had "slight symptoms of pellagra," and it is poss- ible that the apparent lessening of the difference between blacks and whites in the USA is consequent on improving socioeconomic conditions of American blacks. In general, neutrophil counts in American blacks are much closer to those of whites than are the counts of blacks of African and West Indian origin. In our subjects dietary intake of fat was higher in blacks but iron and protein intake was the same as in whites. The mean neutrophil count of $2.65 \times 10^{9} / 1$ which we found is comparable to earlier reports of neutrophil counts from Africa, where various studies had mean counts varying from $2 \cdot 1$ to $2 \cdot 9$ $\times 10^{9} / 1$; $^{15}$ this does not give support to an environmental cause. We have also seen low white cell and neutrophil counts in subjects of West Indian origin who were born or who have lived in the UK for many years. Nevertheless, when data are collected under different circumstances and analysed in different ways they can be compared only in general terms. For example, as our blood samples were collected after 30 minutes' rest the counts may be lower than if subjects had been normally active till the time of venesection. Different methods of statistical analysis may either simulate or obscure ethnic differences_for example, if data have a logarithmic distribution but are analysed as if they are normally distributed then mean values calculated will be too low, and if too few cells are counted the precision of the counts will be less ${ }^{16}$ and true differences between ethnic groups may be obscured. Resolving this issue requires further careful detailed study, with data collected and analysed in a comparable manner. Our finding that Indians in the UK have similar mean neutrophil counts to those of whites accords with previous observations that Indians in east Africa $^{17} 18$ and South Africas have neutrophil counts which are closer to white values than to black African values. The mean monocyte count in each ethnic group was lower than the mean monocyte count in whites.

Previous studies have produced conflicting results as to whether monocyte counts are lower in blacks. Forbes et al' reported lower monocyte counts in American blacks than in whites, but Orfanakis et al ${ }^{13}$ and Karayalcin et $a^{14}$ did not. With regard to blacks of African origin, Shaper and Lewis ${ }^{15}$ reported significantly lower monocyte counts in blacks than in whites, and Wasserman's findings for South African Bantus $^{5}$ were similar. Our findings in blacks of African and West Indian origin thus accord better with previous results in Africans than with previous results in American blacks. We found that the ratio of mean neutrophil count to mean monocyte count in blacks was similar to the ratio we had previously found in whites. ${ }^{19}$ Monocyte counts in Indians have previously been reported to be the same as those in whites. ${ }^{18}$ The magnitude of the difference between 
monocyte counts of whites and of Indians which we observed is not great and there is considerable scatter about the means, which could account for the difference not having been apparent in the earlier study. There are few observations of normal white cell values in subjects of Oriental origin, and we are not aware of the lower mean monocyte count in comparison with whites having been reported.

There have been numerous reports of higher eosinophil counts in blacks of African ${ }^{1517}$ or South African $^{5}$ origin than in whites, and Ezeilo ${ }^{11}$ found that this difference persisted when Africans migrated to Britain. Our finding that African and West Indian eosinophil counts were no higher than white values is of considerable importance and indicates that previously reported raised counts were due to an environmental influence. Parasitic disease has long been suspected as a cause of high eosinophil counts in blacks of African origin, though attempts to confirm the association were not successful. We found that the mean eosinophil count was somewhat higher in Orientals and Indians than in whites and blacks. Only the difference between Orientals (with the highest mean count) and blacks (with the lowest mean count) was significant and then only at the $5 \%$ level. There have been many reports of high eosinophil counts in Indians in the Indian subcontinent and in east Africa. ${ }^{15171820}$ Our mean eosinophil counts are much lower than those previously reported in India and Africa and not significantly different from white values, indicating that an environmental rather than a genetic influence also exists for the higher eosinophil counts previously reported in Indians.

We found no difference in the lymphocyte counts between our four ethnic groups. An inverted neutrophil : lymphocyte ratio is often noted in blacks, but this relative lymphocytosis is due to neutropenia rather than a true lymphocytosis. Observations suggesting an ethnic variation in the lymphocyte count in Indian men in India ${ }^{21}$ were not substantiated in more recent studies of Indians in east Africa. ${ }^{17} 18$ Wasserman $^{5}$ found higher lymphocyte counts in South African Bantu than in whites and Ezeilo found higher counts in African blacks, " but these findings have not been confirmed in any other studies of American or African blacks. ${ }^{12-15} 1718$ Our findings thus support the majority of previous observations that there is no ethnic variation in lymphocyte count.

The only significant difference we found between subjects taking or not taking oral contraceptives was a higher white cell count and neutrophil count in blacks taking oral contraceptives. It is likely that our data overestimate the true difference between white cell count and neutrophil count in these two groups since the difference in total white cell count in the larger group of 265 blacks from which the 158 subjects were drawn was smaller and did not reach statistical significance. ${ }^{9}$ We have been unable to find any bias in the selection of the 158 subjects; the users and non-users of oral contraceptives were collected simultaneously and the only basis for selection was whether the blood film had been discarded through lack of storage space. In the Oriental group the higher white cell count found in oral contraceptive users which was not significant in the study (51 subjects) was significant in the larger study (176 subjects). Published results of the effect of oral contraceptives on the blood count have given conflicting results. Pincus ${ }^{22}$ found that subjects taking oral contraceptives with an oestrogen content of 75-150 $\mu \mathrm{g}$ had higher neutrophil counts than controls, whereas Toth $^{23}$ found that subjects taking preparations with $100 \mu \mathrm{g}$ of oestrogen had lower neutrophil counts than controls. In a study limited to whites we found that oral contraceptives with an oestrogen content of $30-50 \mu \mathrm{g}$ had no effect on the white cell count or neutrophil count. ${ }^{24}$

The lower white cell and neutrophil counts in blacks than in whites, Indians, and Orientals are of considerable practical importance. It is important to avoid unnecessary haematological investigation of healthy "neutropenic" blacks. Conversely, the higher eosinophil counts previously reported in blacks were not present in our study group, and if eosinophil counts in blacks, Orientals, or Indians are above normal ranges for whites, they should be interpreted as evidence of allergy, parasitism, or other disease. The small variations in monocyte counts between different racial groups are not of any practical importance. As our data were collected in fasting and rested subjects they are strictly comparable only with other data collected under the same conditions. Nevertheless, the findings for white women are similar to our previous findings for this group $^{24}$ (when counts were done under varying circumstances), suggesting that our data for the other racial groups also provide acceptable reference ranges for assessing female patients.

We wish to acknowledge support for this study from the Thorn Trust.

\footnotetext{
References

' Forbes WH, Johnson RE, Consolazio F. Leukopenia in Negro workmen. Am J Med Sci 1941;201:407-12.

${ }^{2}$ Broun GO, Herbig FK, Hamilton JR. Leukopenia in Negroes. $N$ Engl J Med 1966;275:1410-3.
} 
${ }^{3}$ Shaper AG, Kyobe J, Stansfield D. Haematological observations on an East African student population. East Afr Med J 1961;39:1-4.

${ }^{4}$ Rippey JJ. Leucopenia in West Indians and Africans. Lancet 1967 ;ii: 44.

${ }^{5}$ Wasserman HP. Leucocyte counts and ESR in Africa. An interracial study and review of the literature. S Afr Med J 1966; 40: suppl 21.

- Shoenfeld Y, Weinberger A, Avishar R, et al. Familial leukopenia among Yemenite Jews. Isr J Med Sci 1978; 14:1271-4.

${ }^{7}$ Brain B, Buckle GC, Jamieson M. Haematological differences in three population groups. S Afr Med J 1979;55:635-6.

${ }^{8}$ Scott TG. A pilot study of the reference values for the commoner haematological and biochemical parameters in Saudi nationals. J Clin Pathol 1982;35:69-73.

9 Godsland IF, Seed M, Simpson R, Broom G, Wynn V. A comparison of haematological indices between women of four ethnic groups and the effect or oral contraceptives. $J$ Clin Pathol 1982;36: 184-91.

${ }^{10}$ Howells DPM. Neutropenia in people of African origin. Lancet 1971;ii: 1318-9.

"Ezeilo GC. Non-genetic neutropenia in Africans. Lancet 1972;ii: $1003-4$.

${ }^{12}$ Shija AK, Wosorne L, Kasobe L. Haematological norms in Zambians with special reference to chemotherapy. Med $J$ Zambia 1978;12:90-2.

${ }^{13}$ Orfanakis NG, Ostlund RE, Bishop CR, Athens JW. Normal blood leukocyte concentration values. Am J Clin Pathol 1970;53:647-51.
${ }^{14}$ Karayalcin G, Rosner F, Sawitsky A. Pseudo-neutropenia in American Negroes. Lancet 1972;i:387.

is Shaper AG, Lewis P. Genetic neutropenia in people of African origin. Lancet 1971;ii:1021-3.

${ }^{16}$ England JM, Bain BJ. Annotation. Total and differential leucocyte count. Br J Haematol 1976;33:1-7

${ }^{17}$ Kasili EG, Cardwell CL, Taylor JR. Leucocyte counts on blood donors in Nairobi. East Afr Med J 1969;46:676-9.

${ }^{18}$ Hawgood BC. Leucocyte levels in East Africa. East Afr Med J 1969;46:680-2.

${ }^{19}$ Bain BJ, Wickramasinghe N. Relationship between the concentration of neutrophils and monocytes in venous blood. Acta Haematol 1976;55:89-94.

${ }^{20}$ Napier LE, Das Gupta CR. Haematological studies in Indians. Indian J Med Res 1935;23:305-9.

${ }^{21}$ Ranalingaswami V, Venkatachalam PS. Haematological studies on healthy adult men in Coonoor and Outacamund. Indian $J$ Med Res 1950;38:2-28.

${ }^{22}$ Pincus G. The control of fertility. New York: Academic Press, 1965:277.

${ }^{23}$ Toth E. The inhibitory effect of anticoncipients on leukocytes in the case of healthy women in their fertile age. 19th Congress of the International Society of Haematology, Budapest: 1982.

${ }^{24}$ Bain BJ, England JM. Normal haematological values: sex difference in neutrophil count. Br Med J 1975;i:306-9.

Requests for reprints to: Dr Barbara J Bain, Department of Haematology, St Mary's Hospital Medical School, London W2 1PG, England. 